\begin{tabular}{lc}
\hline \hline $\begin{array}{l}\text { MINING AND METALLURGY INSTITUTE BOR } \\
\text { UDK: 622 }\end{array}$ & $\begin{array}{l}\text { ISSN: 2334-8836 (Štampano izdanje) } \\
\text { ISSN: 2406-1395 (Online) }\end{array}$ \\
\hline \hline & doi:10.5937/MMEB1503157T \\
UDK: 547.914:622.01:624(045)=111 & \\
Prvoslav Trifunović ${ }^{*}$, Rade Tokalić, Nebojša Vidanović ${ }^{*}$, Draško Marković*
\end{tabular}

\title{
POLYMER RESINS WITH FOAM EFFECT AND THEIR APPLICATION IN MINING****
}

\begin{abstract}
For stabilization of degraded rock massif around the built underground mining premises, the procedures of injecting of polymer synthetic resins with foam effect are in use today more and more. By injecting of polymer resins in drill holes or cracks and their hardening, the spreading of deformity by depth is stopped, and therefore the stability of degraded rock material and built premises is provided.

For increasing the stability of mining premises, the fast reacting phenolic resins are used, filling up the cracks in the cracked rock mass and preventing their expansion. In that way they contribute improving the operative safety and efficiency in building the mining premises.

Few years ago, two-component poliurethan foamy resins appeared that have found an application for strengthening, insulation and rehabilitation of mining premises demanding a medium or longer period of usage.

Urea of silicate non-flammable resin is approved for usage in the coal mines and in building the underground premises in heavy work conditions. Stabilization and strengthening of weaked zones in these cases is done by combining the drainage and injecting the fast reacting foamy resins.

New materials and technologies have enabled very significant improvements in many areas of mining and constructions, both in domain of faster, safer and more efficient building, and in domain of maintenance and rehabilitation the mining and construction facilities.

Keywords: foamy polymer resins, strengthening and stabilization, degraded rock massif, mining, construction, geotechnics
\end{abstract}

\section{INTRODUCTION}

Polymer resins with foam effect have found a wide application in strengthening, stabilization and insulation of degraded materials in mining, geotechnics, hydratechnics, construction and other related activities.

In mining, they have application for stabilization and strengthening of degraded rocks around underground facilities, sto- pping of water inflow, etc. In geotechnics and hydrotechnics, they are used in strengthening of sandy and gravelish soil of constructions with the aim of increasing the bearing capacity; filling of cavities and injecting of cracks of concrete and wall constructions; anchoring of different elements into the built facilities, rocks and groundwork; strengthening of damaged docks and

\footnotetext{
*Univerzity of Belgrade, Faculty of Geology and Mining, Djusina 7, 11000 Belgrade, Serbia, e-mail: prvoslav.trifunovic@rgf.bg.ac.rs

** Administration for Inspection Affairs, Department of Mining, Geological and Inspection for Hydrocarbons, Rimski trg no. 46, 81000 Podgorica, Montenegro

*** This work is the result of the Project No. TR 33029, funded by the Ministry of Education, Science and Technological Development of the Republic of Serbia
} 
pillars of bridges, even bellow water level; preventing of leaking barriers and walls of hydrotechnical dams, insulation of mineral water streaming, etc.

\section{BASIC CHARACTERISTICS OF POLYMER RESINS WITH FOAM EFFECT}

Foam is a gas emulsion of bubbles in injecting mass, arising from ordinary injection mixture by action of reagents for creating of bubbles. Gas bubbles have mostly spherical shape, of uniform diameter, where $80 \%$ of them has diameter $(0.9-1.1) d$, where $d$ is an average diameter depending from type of reagent [1].

Foam is characteristic by two coefficients: expansion coefficient $e$ and overgrowth coefficient $f$.

Expansion coefficient $e$ is a relation between gas volume and suspension volume, and an equivalent to a porosity coefficient with incoherent soil.

Overgrowth coefficient $f$ is a relation between the final and starting foam volume.

If expansion coefficient $e$ is $<0.2$ there is no foam effect, and when $e$ is $>0.8$ foam is getting stiffen. Cement suspension foams can reach a coefficient up to $e=3$, and polymer resins foams can reach coefficient up to e $=50$.

Foam can be produced in suspensions and solutions in two ways:

- By adding of reagent which increases surface tension of water, and mixing creates foam;

- By adding of reagent which in chemical reaction releases gas emulsifies in a bubble shape.

In the first way, foam is created by physical reaction almost in the moment of mixing. Diameter of bubbles is uniform and under one millimeter.

In the second way, foam is created by chemical reaction that needs time from 10 to 20 minutes depending on temperature. That increases the expansion coefficient and improves foam properties, especially its stability.

Due to described characteristics, foams are especially used for closing and filling the large cavities (caverns, systems of large cracks and similar), and mass consumption is small. They are especially suitable for closing of cracks through which water flows, because of sudden stiffening after exit from the injecting pipe, for both, foams and in combination with the cement suspensions.

\section{APPLICATION OF TWO- COMPONENT FAST REACTING POLYMER RESINS IN MINING}

For stabilization, strengthening and insulation of degraded rock massif around built underground premises and objects today are used: two-component fast reacting phenolic resins, two-component polyurethane foamy resins and urea of silicate inflammable resin.

Two-component fast reacting phenolic resins start to foam immediately on mixing, gaining excellent physico-chemical properties. Injecting resin prevents expanding of deformities in cracked rock massif, fills gaps and increases stability of support the mining premises. In that way it contributes to improvement the operative safety and efficiency during performing the mining operations. Increasing of support stability using the fast reacting phenolic resins [5], is schematically shown in Figure 1. 


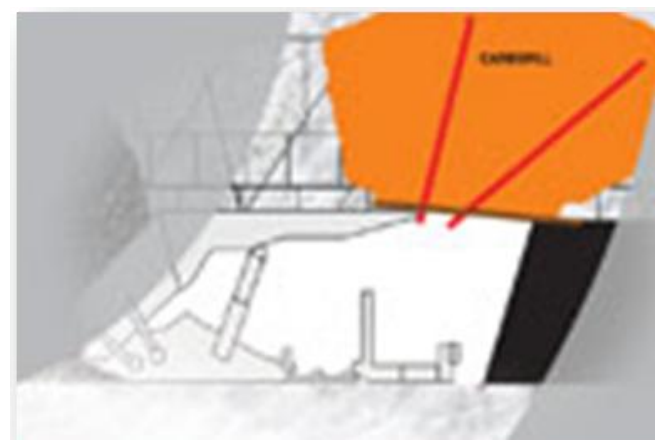

Figure 1 Increasing the support stability using the fast reacting phenolic resins

The base component (A) is made of material based on synthetic resin, and the other component (B) is made of catalyzer-hardener, placed in a small cartridge inside the first one. Mixture is made on the spot in ratio 4:1 using a two-component pump and hose (see Figure 2).

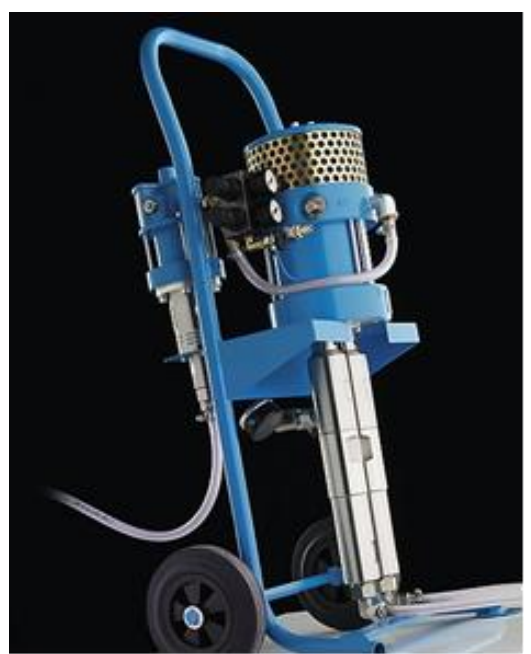

Figure 2 Two-component injecting pump WIVA 2 K-Inject

During mixing it comes to polymerization caused by catalyzer, wherein resin foams, increases volume by several times and gets hard. Injecting mixture can be pumped through hoses, pipes or anchors filled by phenolic resin with catalyzer.

Technical data for components and foamy mass are presented in Tables 1 and 2.

Table 1 Technical data for components

\begin{tabular}{|l|l|c|c|c|}
\hline Components technical data & Unit & \multicolumn{2}{|c|}{ Resin } & Catalyzer \\
\hline Density at $25^{\circ} \mathrm{C}$ & $\mathrm{kg} / \mathrm{cm}^{3}$ & \multicolumn{2}{|c|}{$1290 \pm 30$} & $1540 \pm 30$ \\
\hline pH-value & \multicolumn{2}{|c|}{$\sim 8$} & $1-0$ \\
\hline Expiration date & months & 3 & 12 & 6 \\
\hline Storage temperature & ${ }^{0} \mathrm{C}$ & max. $20^{0}$ & max. $5^{0}$ & $-5^{0}-30^{0}$ \\
\hline
\end{tabular}


Table 2 Technical data for resin-foamy mixture

\begin{tabular}{|l|c|c|}
\hline Technical data for resin-mixture $\left(\right.$ on $\left.20^{\circ} \mathrm{C}\right)$ & Unit & Mixture \\
\hline Starting time of binding & $\mathrm{s}$ & immediately \\
\hline Reacting time & $\mathrm{s}$ & $180 \pm 60$ \\
\hline Expansion coefficient (e) & & $32-38$ \\
\hline Consumption & $\mathrm{kg} / \mathrm{m}^{3}$ & $\sim 36-42$ \\
\hline
\end{tabular}

Two-component polyurethane foamy resins are used for strengthening and insulation the rocks, soil, or constructions in the mines, geotechnical underground and construction engineering. Polyurethane resins are suitable for repair, reinforcement and insulation the cracks in concrete constructions and walls, achieving the high level of adhesion. Some types can be used for insulating of cracked constructions against penetration of water and gas. Foamy types have thermal and soundproof insulation properties.

Application of polyurethane foamy resins injecting technology in mining and tunnel construction is reflectedin the following [8]:

- Strengthening of rock massif with improving the mechanical properties of rock environment,

- Improving of mechanical properties of exploited materials before exploitation,

- Decreasing and preventing the water flow in mines,

- Anchoring and rock stabilization,
- Decreasing of gas penetration in the mine area,

- Preventing of unwanted gas leaking from mine into the environment,

- Preventing of waste water flowing from the abandoned mine areas,

- Preventing of flowing the unwanted air currents in the mine,

- Filling of cracks of multiple broken rocks,

- Injecting of dams and their environment with the aim to prevent water infiltration,

- Anchoring and injecting of coal surface during exploitation,

- Injecting of rocks of small stability in building the tunnels and excavation the horizontal pit premises, and

- Securing the mine operation movement over the techtonic damages.

Some examples of using the polyurethane resins in mining [2] are shown in $\mathrm{Fi}_{-}$ gures 3 and 4 .

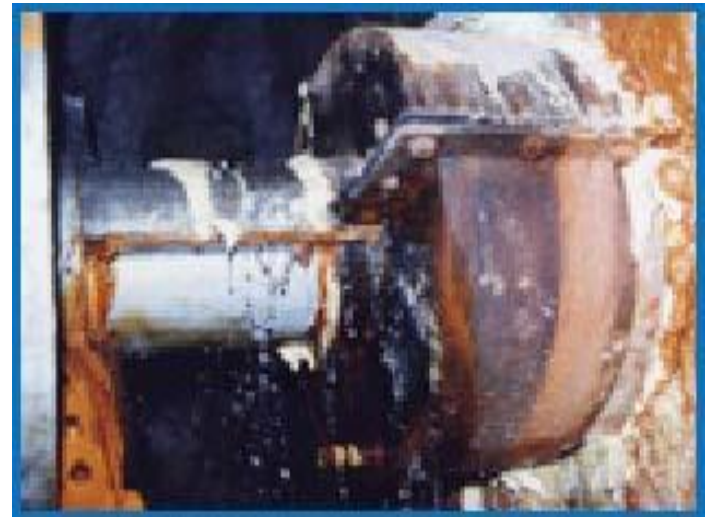

Figure 3 Injecting of water barrier in the coal mines with the aim to prevent flowing of water through a barrier; the used material - Geopur

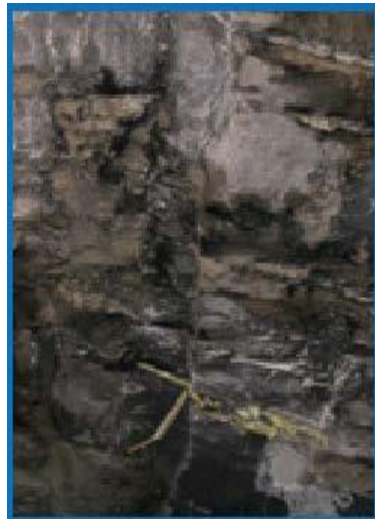

Figure 4 Sealing of cracks in a coal mine 
Two-component resin consists of component $\mathrm{A}$ and $\mathrm{B}$. Component $\mathrm{A}$ is a liquid of honey color (all types), consisting of mixture of: polyalcohol, accelerators, compounds reducing flammability, foam stabilizers and water. Component B is a dark brown - yellow liquid (all types), made of: polymethilene, polyphenylisocyants, diphenylmethane, disocyanate (MDI) and mixture of polycyclic oligomers depending on a function.

After mixing the two basic components in a given proportion, through exothermic reaction, apolyurethane resin is formed. Degree of resin foam determines its physical and chemical characteristics. Start foaming and hardening reaction can be delayed for all systems up to 360 seconds. Standard compositions of these resins start to foam in 2 minutes. Delaying of reaction can be achieved only while components are still not mixed adding the special additives [8].

Urea of silicate inflammable resin is approved for use in the coal mines and in building the underground premises in heavy work conditions. Stabilization and strengthening of weaked zones around underground premises are performed by combination of drainage and injecting of fast reacting foamy resins [4].

Urea of silicate resin fulfills the modern requests of tunnel construction and building the underground premises in mining. Large number of these resins is produced from one-component resins for small works in preventing the water flow, to special robust two-component systems for efficient solving the problems of massif water penetration.

Properties and advantages of urea silicate injecting resins: besides they are "designed specifically" for tunnel construction and mining, these resins are without solvents and form a cell structure from foam. For many urea silicate resins using in preventing of water in tunnel construction, the usage of various accelerators on the spot can adjust properties to match the concrete work conditions. Large number of urea silicate resins is on the market whose usage improves the fire protection and increases the safety in tunnel construction and mining.

Comparative review of polyurethane resins and urea silicate resins $[8,4]$ is given in Table 3 .

Table 3 Polyurethane (PU) and urea silicate resins

\begin{tabular}{|c|c|c|c|c|}
\hline Type of resin & Reaction time $\left(25^{\circ} \mathrm{C}\right)$ & $\begin{array}{l}\text { Foam } \\
\text { factor }\end{array}$ & Usage & Equipment \\
\hline $\begin{array}{l}\text { one-component } \\
\text { PU + accelerator }\end{array}$ & $30-100$ s on $20^{\circ} \mathrm{C}$ & 1.8 & $\begin{array}{l}\text { For permanent sealing of structure cracks of concrete and masonry } \\
\text { constructions, filling of dry and cracks with lying water. }\end{array}$ & $\begin{array}{l}\text { One-component } \\
\text { pump }\end{array}$ \\
\hline $\begin{array}{l}\text { One-component } \\
\mathrm{PU}+\text { accelerator }\end{array}$ & $\begin{array}{l}10-120 \mathrm{~s} \\
\text { Separated accelerator } \\
\text { enables adjusting of } \\
\text { reaction time }\end{array}$ & $20-30$ & $\begin{array}{l}\text { For preventing of water penetration in tunnels. Gravel } \\
\text { consolidation.Sealing of cracks in concrete structure. }\end{array}$ & $\begin{array}{l}\text { One-component } \\
\text { pump }\end{array}$ \\
\hline $\begin{array}{l}\text { One-component } \\
\text { PU + accelerator }\end{array}$ & $\begin{array}{l}15-130 \mathrm{~s} \\
\text { Separated accelerator } \\
\text { enables adjusting of } \\
\text { reaction time. }\end{array}$ & $20-30$ & $\begin{array}{l}\text { For preventing of water penetration in tunnels. Gravel consolidation. } \\
\text { Sealing of cracks in concrete constructions for drinking water. }\end{array}$ & $\begin{array}{l}\text { One-component } \\
\text { pump }\end{array}$ \\
\hline \multirow[t]{3}{*}{ Two-component PU } & Without accelerator & $1-10$ & \multirow{3}{*}{$\begin{array}{l}\text { Soil consolidation and fast preventing of water in underground } \\
\text { objects. Not to be used in mines due to high reaction } \\
\text { temperature. Reactive with and without water. } \\
\text { Using of accelerator } 10 \text { enables increase of foam factor and faster } \\
\text { reaction in cases of big water penetration. Using of accelerator } 15 \\
\text { secures stiffer foam with significant improve of soil properties. } \\
\end{array}$} & \multirow{3}{*}{$\begin{array}{l}\text { Two-component } \\
\text { pump and static } \\
\text { mixer. }\end{array}$} \\
\hline & Accelerator 10 & $10-20$ & & \\
\hline & Accelerator 15 & $1-8$ & & \\
\hline $\begin{array}{l}\text { High-reacting two- } \\
\text { component PU }\end{array}$ & $\begin{array}{l}\text { Accelerator } 25 \\
20-60 \mathrm{~s}\end{array}$ & $2 \cdot 15$ & $\begin{array}{l}\text { Fast reacting PU resin, uses in very demanding conditions to stop } \\
\text { water. Resin secures current structure hardness. }\end{array}$ & $\begin{array}{l}\text { Two-component } \\
\text { pump and static } \\
\text { mixer }\end{array}$ \\
\hline Two-component PU & $30-70 \mathrm{~s}$ & $2-3$ & $\begin{array}{l}\text { High quality foam for rock and soil consolidation in mines and } \\
\text { geotechnical works. It could react by stronger expansion in presence } \\
\text { of water from deposits. }\end{array}$ & $\begin{array}{l}\text { Two-component } \\
\text { pump and static } \\
\text { mixer }\end{array}$ \\
\hline $\begin{array}{l}\text { Two-component urea } \\
\text { silicate without solvent, } \\
\text { fire-resistant }\end{array}$ & $90-150 \mathrm{~s}$ & 1 & $\begin{array}{l}\text { Thick resin, similar to glue, with good penetrating properties for very } \\
\text { efficient consolidation of cracked and soft rocks in coal mines. Does } \\
\text { not make foam in contact with water. It could be used for injecting } \\
\text { under water. }\end{array}$ & $\begin{array}{l}\text { Two-component } \\
\text { pump and static } \\
\text { mixer }\end{array}$ \\
\hline $\begin{array}{l}\text { Two-component urea } \\
\text { silicate without solvent, } \\
\text { fire-resistant resin }\end{array}$ & $10-50 \mathrm{~s}$ & $20-30$ & $\begin{array}{l}\text { Filling of cavities in tunnels and mines with improved properties of } \\
\text { resistance on fire. Expands without water. }\end{array}$ & $\begin{array}{l}\text { Two-component } \\
\text { pump and static } \\
\text { mixer }\end{array}$ \\
\hline
\end{tabular}


The large world producers produce the polyurethane resins with foam effect under different commercial names: Carbofill, Carbopur, Geopur, WilkitFoamT, MEYCO, etc.

\section{CONCLUSION}

Modern materials based on polymer mixtures have increasing application for stabilization, strengthening and insulation the degraded rock massif in mining and construction area.

Polymer resins are widely used for strengthening the contours of mining premises and construction objects, if they are making in degraded environment, cracked and splitted rock massif or in case of unbidden sediments. The main advantages are: simple application, fast reaction and capability to stabilize whole formations of surrounding rocks exposed to the high pressures and movements.

Application of technology of injecting polyurethane resins in mining reflects in the next: strengthening of surrounding rock mass with achieving a high hardness under tightening and under pressure; decrease and stopping of water flow in the mines; anchoring and stabilization of rocks; decrease of gas penetration in the mine area; preventing of unwanted gas leakage from mine in the environment; preventing the waste water run out from the abandoned areas of mine; preventing of running out of unwanted air currents in mine; filling of cracks of multiple broken rocks; anchoring and injecting of coal surface during exploitation; providing of work moving in mine over tectonic damages and other.
Choice of polymer material is made individually for all specific cases under construction and recovery of underground mining and construction facilities, depending on requested stability and functionality of facilities in a specific time period.

\section{REFERENCES}

[1] Culibrk R. (2001), Geotechnical Works in Solid Rocks, Faculty of construction, Subotica, pp. 120-126, 169-178, 246-250;

[2] Bolesta M., Eichstaedt F., Hoffmann P. (1997), Recommendations for the Selection and Application of Injection Products for Ground Consolidation, Glückauf Int. Ed. 133 pp.550-559;

[3] Code SIA 267/1 (2003), Geotehnical Design - Supplementary Specifications, Swiss Society of Engineers and Architects, Zurich;

[4] Cornely W.(2003), Elastifield Silicate Resins and Polyuretane Foam Resins for the Stabilisation of Strata - a Comparison.

[5] V. V. Vasilev, (1986): Polymernye Kompozicii v gornom dele, Moscow, p.57ff.;

[6] Cokorilo V. et al., (2002), Rationalization and Modernization of Building and Supporting of Mining Premises in Mines with Underground Exploitation, Study, Codel Engineering, Belgrade, pp. 211-233;

[7] Nonveiller E. (1989): Injection of Soil, Theory and Practice, Zagreb, School book, pp. 47-50, 74-82.

[8] Polyurethane Resins: Geopure, www.geopurewt.com 


\begin{tabular}{ll}
\hline \hline INSTITUT ZA RUDARSTVO I METALURGIJU BOR & ISSN: 2334-8836 (Štampano izdanje) \\
UDK: 622 & ISSN: 2406-1395 (Online) \\
\hline \hline
\end{tabular}

UDK: 547.914:622.01:624(045)=163.41

doi:10.5937/MMEB1503157T

Prvoslav Trifunović, Rade Tokalić, Nebojša Vidanović, ${ }^{*}$ Draško Markovic ${ }^{* * *}$

\section{POLIMERNE SMOLE SA EFEKTOM PENE I NJIHOVA PRIMENA U RUDARSTVU**}

Izvod

Za stabilizaciju degradiranog stenskog masiva oko izrađenih podzemnih rudarskih prostorija danas se sve više koriste postupci injektiranja polimernih sintetičkih smola sa efektom pene. Injektiranjem polimernih smeša u bušotine ili pukotine i njihovim očvršćavanjem sprečava se širenje deformacija po dubini, a samim tim obezbeđuje stabilnost degradiranog stenskog materijala i izrađenih objekta.

Za povećanje stabilnosti rudničkih prostorija najčešće se koriste brzo reagujuće fenolne smole koje popunjavaju pukotine u raspucaloj stenskoj masi i sprečavaju njihovo širenje. Na taj način doprinose poboljšanju operativne sigurnosti i efikasnosti pri izradi rudničkih prostorija.

Pre nekoliko godina u upotrebu su ušle dvokomponentne poliuretanske penušave smole, koje su našle primenu za ojačanje, izolaciji i sanaciju rudarskih prostorija koje zahtevaju srednji ili duži rok korišćenja.

Urea silikatne nezapaljive smole odobrene su za korišćenje u rudnicima uglja i kod izrade podzemnih objekata u teškim radnim uslovima. Stabilizacija $i$ ojačanje oslabljenih zona $u$ ovim slučajevima vrši se kombinacijom dreniranja i injektiranja brzo reaktivnih penušavih smola.

Novi materijali i tehnologije omogućili su da se u mnogim oblastima rudarstva $i$ građevinarstva postižu veoma značajna poboljšanja kako u domenu brže, sigurnije i efikasnije gradnje, tako i u domenu održavanja i sanacije radarskih i građevinskih objekata.

Ključne reči: penušave polimerne smě̌e, ojačanje i stabilizacija, degradirani stenski masiv, rudarstvo, građevinarstvo, geotehnika

\section{UVOD}

Polimerne smole sa efektom pene našle su široku primenu za ojačanje, stabilizaciju i izolaciju degradiranih materijala u rudarstvu, geotehnici, hidrotehnici, građevinarstvu i drugim srodnim delatnostima.

U rudarstvu se koriste za stabilizaciju i ojačanje degradiranih stena oko podzemnih prostorija, stabilizaciju ispucalih slojeva uglja, popunjavanje pukotina i velikih šup- ljina oko podzemnih objekata, zaustavljanje dotoka voda itd. U geotehnici i hidrotehnici se koriste za ojačavanje peskovitog i šljunkovitog tla konstrukcija u cilju povećanja nosivosti; ispunjavanje šupljina i injektiranje prslina betonskih i zidanih konstrukcija; ankerisanje različitih elemenata $\mathrm{u}$ izrađene objekte, stene i podlogu; ojačavanje oštećenih dokova i stubova mostova čak i

\footnotetext{
*Univerzitet u Beogradu, Rudarsko-geološki fakultet, Đušina 7, 11000 Beograd, Srbija, e-mail: prvoslav.trifunovic@rgf.bg.ac.rs

${ }^{* *}$ Uprava za inspekcijske poslove, Odsjek za rudarsku, geološku i inspekciju za ugljovodonike, Rimski trg br. 46, 81000 Podgorica

**** Ovaj rad je proistekao iz Projekta br. TR 33029 koji je finansiran sredstvima Ministarstva prosvete, nauke i tehnološkog razvoja Republike Srbije.
} 
ispod nivoa vode; sprečavanje procurivanja barijera i zidova hidrotehničkih brana, izolaciju dotoka mineralnih voda i dr.

\section{OSNOVNE KARAKTERISTIKE POLIMERNIH SMOLA SA EFEKTOM PENE}

Pena je gasna emulzija mehurića u injekcionoj smesi, koja nastaje iz obične injekcione smeše delovanjem reagenasa za stvaranje mehurića. Gasni mehurići su pretežno sferičnog oblika, jednoličanog prečnika, pri čemu $80 \%$ njih ima prečnik $(0,9-1,1) d$, gde je $d$ prosečni prečnik koji zavisi od vrste reagensa [1].

Penu karakterišu dva koeficijenta: koeficijent ekspanzije e i koeficijent bujanja f.

Koeficijent ekspanzije e je odnos između zapremine gasa i zapremine suspenzije, a ekvivalentan je koeficijentu poroznosti kod nekoherentnog tla.

Koeficijent bujanja $f$ je odnos između konačne i početne zapremine pene.

Ako je koeficijent ekspanzije e $<0,2$ nema efekta pene, a kad je e $>0,8$ pena se ukrućuje. Pene od cementnih suspenzija postižu koeficijent do $\mathrm{e}=3$, a pene od polimernih smola mogu postići koeficijent $i$ do e $=50$.

Pena se može proizvesti u suspenzijama i rastvorima na dva načina:

- dodavanjem reagensa koji povećava površinski napon vode, pa mešanjem nastaje pena;

- dodavanjem reagensa koji hemijskom reakcijom oslobađa gas koji se emulgira u obliku mehurića.

Prvim načinom, pena nastaje fizičkom reakcijom gotovo u trenutku mešanja. Prečnik mehurića je jednoličan i manji je od jednog milimetra. Drugim načinom, pena nastaje hemijskom reakcijom, što zahteva vreme od 10 do 20 minuta u zavisnosti od temperature. Prečnik mehurića nije jednoličan, a najveći je do nekoliko milimetara.

Kombinacijom oba postupka može se proširiti raspon između najmanjih i najvećih mehurića. To povećava koeficijent ekspanzije i poboljšava svojstva pene, naročito njenu stabilnost.

Zbog opisanih svojstava, pene se naročito koriste za zatvaranje i ispunjavanje velikih šupljina (kaverne, sistemi velikih pukotina i sl.), a utrošak mase je mali. Posebno su pogodne za zatvaranje pukotina kroz koje teče voda, zbog naglog ukrućenja nakon izlaska iz injekcione cevi, kako samih pena tako i u kombinaciji sa cementnim suspenzijama.

\section{PRIMENA DVOKOMPONENTNIH BRZO REAGUJUĆIH POLIMERNIH SMOLA U RUDARSTVU}

Za stabilizaciju, ojačanje i izolaciju degradiranog stenskog masiva oko izrađenih podzemnih prostorija i objekata u rudarstvu danas se koriste: dvokomponentne brzo reagujuće fenolne smole, dvokomponente poliuretanske penušave smole $\mathrm{i}$ urea silikatne nezapaljive smole.

Dvokomponentne brzo reagujuće fenolne smole počinju da pene odmah pri mešanju, pri čemu dobijaju odlične fizičko-mehaničke osobine. Injektirana smola sprečava širenje deformacija $u$ ispucaloj stenskoj masi, popunjava pukotine, povećava stabilnost podgrade rudničkih prostorija. Na taj način doprinosi poboljšanju operativne sigurnosti i efikasnosti pri izvođenju rudarskih radova. Povećavanje stabilnosti podgrade korišćenjem brzo reagujućih fenolnih smola [5], šematski je prikazano na sl. 1. 


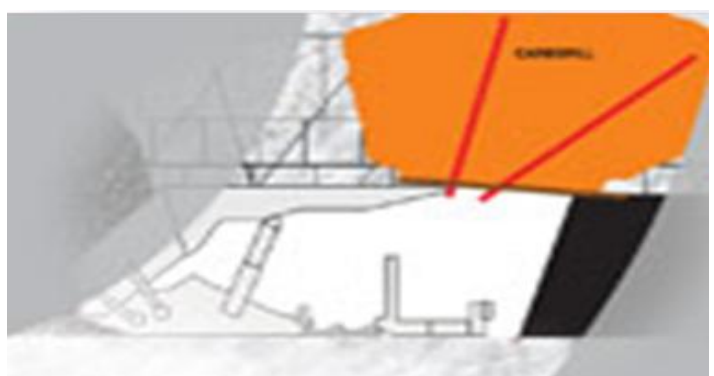

SI. 1. Povećavanje stabilnosti podgrade korišćenjem brzo reagujućih fenolnih smola

Osnovu komponentu (A) čini material na bazi sintetičke smole, a drugu komponentu (B) katalizator-učvršćivač, koji se nalazi u manjoj patroni unutar prve. Smeša se spravlja na licu mesta u razmeri 4:1, korišćenjem dvokomponente pumpe i creva (v. sl. 2.).

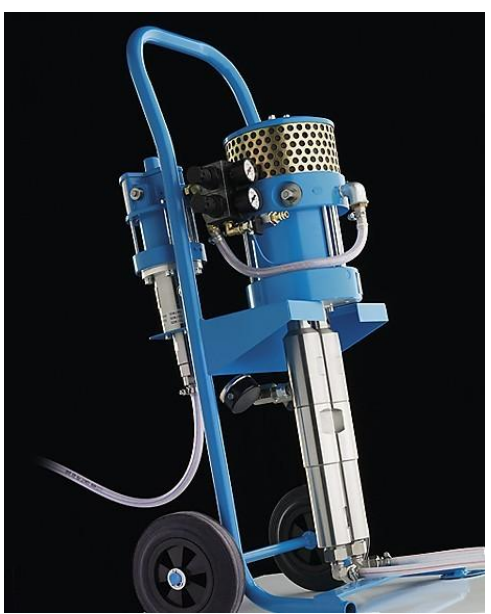

Sl. 2. Dvokomponentna pumpa za injektiranje WIWA 2 K-Inject

Prilikom mešanja dolazi do polimerizacije koju izaziva katalizator, pri čemu smola penuša, uvećava zapreminu nekoliko puta i očvršćava. Injekciona smeša može da se umumpava kroz creva, cevi ili ankere koji su ispunjeni fenolnom smolom sa katalizatorom.

Tehnički podaci za komponente i penastu mešavinu dati su u tabeli 1 i 2.

Tabela 1. Tehnički podaci za komponente

\begin{tabular}{|l|c|c|c|c|}
\hline Tehnički podaci za komponente & Jedinica & \multicolumn{2}{|c|}{ Smola } & Katalizator \\
\hline Gustina na $25^{0} \mathrm{C}$ & $\mathrm{kg} / \mathrm{cm}^{3}$ & \multicolumn{2}{|c|}{$1290 \pm 30$} & $1540 \pm 30$ \\
\hline pH-vrednost & \multicolumn{2}{|c|}{$\sim 8$} & $1-0$ \\
\hline Rok trajanja & meseci & 3 & 12 & 6 \\
\hline Temperatura skladištenja & ${ }^{0} \mathrm{C}$ & $\max .20^{0}$ & $\max .5^{0}$ & $-5^{0}-30^{0}$ \\
\hline
\end{tabular}


Tabela 2. Tehnički podaci za smolu-penastu mešavinu

\begin{tabular}{|l|c|c|}
\hline Tehnički podaci smola-mešavine (na $\left.\mathbf{2 0}^{\mathbf{0}} \mathbf{C}\right)$ & Jedinica & Mešavina \\
\hline Vreme početka vezivanja & $\mathrm{s}$ & odmah \\
\hline Reagujuće vreme & $\mathrm{s}$ & $180 \pm 60$ \\
\hline Koeficijent ekspanzije (e) & & $32-38$ \\
\hline Potrošnja & $\mathrm{kg} / \mathrm{m}^{3}$ & $\sim 36-42$ \\
\hline
\end{tabular}

Dvokomponente poliuretanske penušave smole se koriste za ojačanje i izolaciju stena, zemljišta ili konstrukcija u rudnicima, geotehničkom podzemnom i građevinskom inženjeringu. Poliuretanske smole su prikladne za popravku, armiranje i izolaciju pukotina u betonskim konstrukcijama i zidovima, pri čemu postižu veliki stepen adhezije. Neki tipovi mogu da se koriste za izolaciju ispucalih konstrukcija protiv prodora vode i gasa. Penušavi tipovi imaju svojstva termičke i zvučne izolacije.

Primena tehnologije injektiranja poliuretanskih penušavih smola u rudarstvu i tunelogradnji ogleda se u sledećem [8]:

- Ojačavanje stenske mase uz poboljšavanje mehaničkih svojstava stenske okoline.

- Poboljšanje mehaničkih svojstava eksploatisanih materijala pre eksploatacije.

- Smanjivanje i sprečavanje doticanja vode u rudnike.
- Ankerisanje i stabilizacija stena

- Smanjenje prodiranja gasa u oblast rudnika.

- Sprečavanje neželjenog isticanja gasa iz rudnika u okolinu.

- Sprečavanje isticanja otpadnih voda iz napuštenih oblasti rudnika.

- Sprečavanje proticanja neželjenih vazdušnih struja u rudniku.

- Ispunjavanje pukotina višestruko izlomljenih stena.

- Injektiranje brana i njihove okoline radi sprečavanja infiltracije vode.

- Ankerisanje i injektiranje površine uglja za vreme eksploatacije.

- Injektiranje stena male stabilnosti pri izradi tunela $\mathrm{i}$ iskopavanju horizontalnih jamskih prostorija.

- Obezbeđivanje prelaza radova $u$ rudniku preko tektonskih oštećenja.

Neki primeri upotrebe poliuretanskih smola u rudarstvu [2] dati su na sl. 3 i 4.

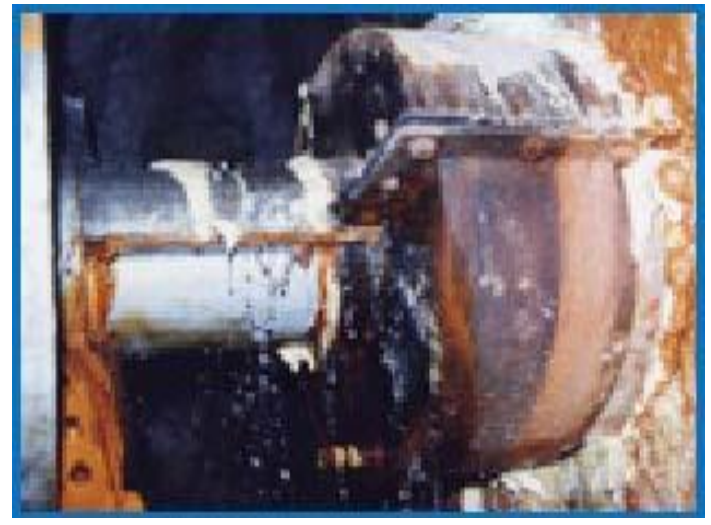

Sl. 3. Injektiranje vodene barijere $u$ rudnicima uglja $u$ cilju sprečavanja proticanja vode kroz barijeru; upotrebljeni materijal Geopur

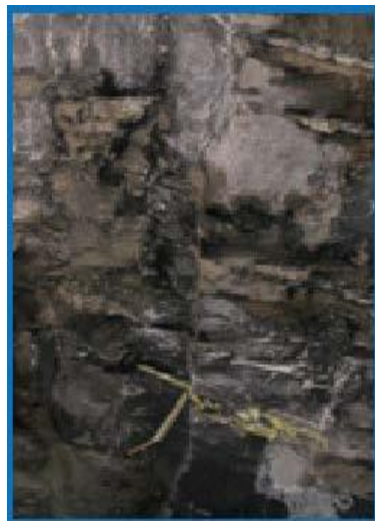

Sl. 4. Zaptivanje pukotina $u$ rudniku uglja 
Dvokomponentna smeša sastoji se od komponente A i B. Komponenta A je tečnost boje meda (svi tipovi), sastoji se od mešavine: polialkohola, akceleratora, jedinjenja koja redukuju zapaljivost, stabilizatora pene i vode. Komponenta B je tamno braon - žuta tečnost (svi tipovi), sastavljena od: polimetilena, polifenilizocijanata, difenilmetana, dizocijanata (MDI) i mešavine policikličnih oligomera zavisno od funkcije.

Nakon mešanja dve osnovne komponente $\mathrm{u}$ datoj razmeri, egzotermnom reakcijom, nastaje poliuretanska smola. Stepen penušavosti smole determiniše njena fizičko-mehanička svojstva. Početak reakcije penušanja i očvršćavanja može se odložiti za sve sisteme do 360 sekundi. Standardni sastavi ovih smola počinju da pene kroz 2 minuta. Odlaganje početka reakcije može se ostvariti samo dok komponente nisu još pomešane, dodatkom specijalnih aditiva [8].

Urea silikatne nezapaljive smole odobrene su za korišćenje u rudnicima uglja i kod izrade podzemnih objekata $\mathrm{u}$ teškim radnim uslovima. Stabilizacija i ojačanje oslabljenih zona oko podzemnih prostorija vrši se kombinacijom dreniranja i injektiranja brzo reaktivnih penušavih smola [4].

Urea silikatne smole zadovoljavaju savremene zahteve tunelogradnje i izrade podzemnih prostorija u rudarstvu. Proizvodi se veliki broj ovih smola od jednokomponentnih smola za male poslove na zaustavljanju dotoka voda, do specijalnih robusnih dvokomponentnih sistema za efikasno rešavanje problema sa masivnim prodorom vode.

Osobine i prednosti urea silikatnih injekcionih smola, osim što su "namenski projektovane" za tunelogradnju i rudarstvo, ove smole su bez rastvarača i formiraju ćelijastu strukturu od pene. Mnogim urea silikatnim smolama koje se koriste za zaustavljanje vode u tunelogradnji, mogu se korišćenjem različitih ubrzivača, na licu mesta, podesiti osobine da odgovaraju konkretnim radnim uslovima. Na tršištu postoji veliki broj urea silikatnih smola, čijim korišćenjem se poboljšava protivpožarna zaštita i povećava sigurnost u tunelogradnji i rudarstvu.

Uporedni pregled poliutretanskih penušavih smola i urea silikatnih smola $[8,4]$ dat je u tabeli 3 .

Tabela 3. Poliuretanske (PU) i urea silikatne smole

\begin{tabular}{|c|c|c|c|c|}
\hline Vista smole & Vreme reakcije $\left(25^{\circ} \mathrm{C}\right)$ & $\begin{array}{l}\text { Faktor } \\
\text { pene }\end{array}$ & Upotreba & Oprema \\
\hline $\begin{array}{l}\text { jedno-komponentni } \\
\text { PU + ubrzivać }\end{array}$ & $30-100$ s na $20^{\circ} \mathrm{C}$ & 1.8 & $\begin{array}{l}\text { Za trajno zaptivanje strukturnih pukotina betona i zidanih } \\
\text { konstrukcija, punjenje suvih i pukotina sa leżecom vodom. }\end{array}$ & $\begin{array}{l}\text { jedno komponentna } \\
\text { pumpa }\end{array}$ \\
\hline $\begin{array}{l}\text { jedno-komponentni } \\
\text { PU + ubrzivać }\end{array}$ & $\begin{array}{l}\text { 10-120s } \\
\text { Odvojeni ubrzivac } \\
\text { omogucava podešavanje } \\
\text { vremena reakcije. }\end{array}$ & $20-30$ & $\begin{array}{l}\text { Za zaustavljanja prodora vode u tunelima. Konsolidacija șjunka. } \\
\text { Zaptivanje pukotina u betonskoj strukturi. }\end{array}$ & $\begin{array}{l}\text { jedno komponentna } \\
\text { pumpa }\end{array}$ \\
\hline $\begin{array}{l}\text { jedno-komponentni } \\
\text { PU + ubrzivać }\end{array}$ & $\begin{array}{l}15-130 s \\
\text { Odvojeni ubrzivač } \\
\text { omogucava podesavanje } \\
\text { vremena reakcije. }\end{array}$ & $20-30$ & $\begin{array}{l}\text { Za zaustavljanja prodora vode u tunelima. Konsolidacija șljunka. } \\
\text { Zaptivanje pukotina u betonskim konstrukcijama za pitku vodu. }\end{array}$ & $\begin{array}{l}\text { jedno komponentna } \\
\text { pumpa }\end{array}$ \\
\hline \multirow[t]{3}{*}{ dvo-komponentni PU } & Bez ubrzivaća & $1-10$ & \multirow{3}{*}{ 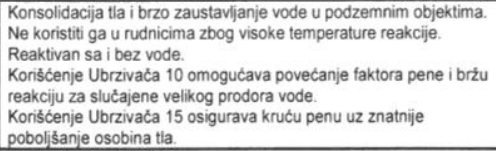 } & \multirow{3}{*}{$\begin{array}{l}\text { dvo komponentna } \\
\text { pumpa i statićna } \\
\text { meśalica }\end{array}$} \\
\hline & Ubrzivaćc 10 & $10-20$ & & \\
\hline & Ubrzivać 15 & 1.8 & & \\
\hline $\begin{array}{l}\text { Visokoreaktivni dvo- } \\
\text { komponentni PU }\end{array}$ & $\begin{array}{l}\text { Ubrzivać } 25 \\
20-60 \text { s }\end{array}$ & $2 \cdot 15$ & $\begin{array}{l}\text { Brzo reaktivna PU smola, koristi se za veoma zahtevne uslove } \\
\text { zaustavijanja vode. Smola osigurava trenutnu strukturnu civrstocu. }\end{array}$ & $\begin{array}{l}\text { dvo komponentna } \\
\text { pumpa i staticna } \\
\text { mešalica }\end{array}$ \\
\hline dvo-komponentni PU & $30-70 \mathrm{~s}$ & $2 \cdot 3$ & $\begin{array}{l}\text { Visoko kvalitetna pena za konsolidaciju strena i tla u rudnicima i } \\
\text { geotehnickim radovioma. Może reagovati snażnijom ekspanzijom u } \\
\text { prisustvu vode iz naslaga. }\end{array}$ & $\begin{array}{l}\text { dvo komponentna } \\
\text { pumpa i statićna } \\
\text { meśalica }\end{array}$ \\
\hline $\begin{array}{l}\text { dvo-komponentni, urea } \\
\text { silikat bez rastvaraca, } \\
\text { vatrootporna smola }\end{array}$ & $90-150 \mathrm{~s}$ & 1 & $\begin{array}{l}\text { Gusta smola, slićna lepku, sa dobrim osobinama prodiranja za } \\
\text { veoma efikasnu konsolidaciju ispucalih i mekih stena u rudnicima } \\
\text { uglja. Ne peni u kontaktu s vodom. Może se koristiti za injektiranje } \\
\text { pod vodom. }\end{array}$ & $\begin{array}{l}\text { dvo komponentna } \\
\text { pumpa i statićna } \\
\text { mesalica }\end{array}$ \\
\hline $\begin{array}{l}\text { dvo-komponentni, urea } \\
\text { silikat bez rastvaraça, } \\
\text { vatrootporna smola }\end{array}$ & $10-50 \mathrm{~s}$ & $20-30$ & $\begin{array}{l}\text { Popunjavanje śuplina u tunelima i rudnicima sa poboljšanim } \\
\text { osobinama otpornosti na pożar. Ekspandira bez vode. }\end{array}$ & $\begin{array}{l}\text { dvo komponentna } \\
\text { pumpa istatićna } \\
\text { meśalica }\end{array}$ \\
\hline
\end{tabular}


Veliki svetski proizvođači proizvode poliuretanske smole sa efektom pene pod različitim komercilanim imenima: Carbofill, Carbopur, Geopur, WilkitFoam T, MEYCO itd.

\section{ZAKLJUČAK}

Savremeni materijali na bazi polimernih smeša imaju sve veću primenu za stabilizaciju, ojačanje i izolaciju degradiranog stenskog masiva u oblasti rudarstva i građevinarstva.

Polimerne smeše široko se koriste za ojačanje kontura rudarskih prosotrija i građevinskih objekata, ukoliko se one izvode u degradiranoj sredini, ispucalom i pukotinski izdeljenom stenskom masivu ili u slučaju nevezanih sedimenata. Glavne prednosti su im: jednostavna primena, brza reakcija i sposobnost da stabilizuje čitave formacije okolnih stena izložene visokim pritiscima i pokretima.

Primena tehnologije injektiranja poliuretanskih smola $\mathrm{u}$ rudarstvu se ogleda $\mathrm{u}$ sledećem: ojačavanje okolne stenske mase uz postizanje velike čvrstoće pri zatezanju i pri pritisku; smanjivanje i sprečavanje doticanja vode u rudnike; ankerisanje i stabilizacija stena; smanjenje prodiranja gasa u oblast rudnika; sprečavanje neželjenog isticanja gasa iz rudnika u okolinu; sprečavanje isticanja otpadnih voda iz napuštenih oblasti rudnika, sprečavanje proticanja neželjenih vazdušnih struja u rudniku; ispunjavanje pukotina višestruko izlomljenih stena; ankerisanje i injektiranje površine uglja za vreme eksploatacije; obezbeđivanje prelaza radova u rudniku preko tektonskih oštećenja i dr.
Izbor polimernog materijala vrši se pojedinačno za svaki konkretni slučaj pri gradnji i sanaciji podzemnih rudarskih i građevinskih objekata, zavisno od tražene stabilnosti i funkcionalnosti objekata $\mathrm{u}$ određenom vremenskom periodu.

\section{LITERATURA}

[1] Ćulibrk R. (2001), Geotehnički radovi u čvrstim stenama, Građevinski fakultet, Subotica, str. 120-126, 169-178, 246-250.

[2] Bolesta M., Eichstaedt F., Hoffmann P. (1997), Recommendations for the Selection and Application of Injection Products for Ground Consolidation, Glückauf Int. Ed. 133 pp.550-559.

[3] Code SIA 267/1 (2003), Geotehnical design - supplementary specifications, Swiss Society of Engineers and Architects, Zurich.

[4] Cornely W.(2003), Elastifield silicate resins and polyuretane foam resins for the stabilisation of strata - a comparison.

[5] V. V. Vasilev, (1986): Polymernye Kompozicii v gornom dele, Moscow, p.57ff.

[6] Čokorilo V. i dr., (2002), Racionalizacija i modernizacija izrade i podgrađivanja rudarskih prostorija u rudnicima sa podzemnom eksploatacijom, studija, Codel inženjering, Beograd, str. 211-233.

[7] Nonveiller E. (1989): Injiciranje tla, teorija i praksa, Zagreb, Školska knjiga, str. 47-50, 74-82.

[8] Poliuretanske smole: Geopure, www.geopurewt.com 